In this issue:

ACRL Officers for $1976 / 77$

News From the Field

ACRL at the '76 Conference

People

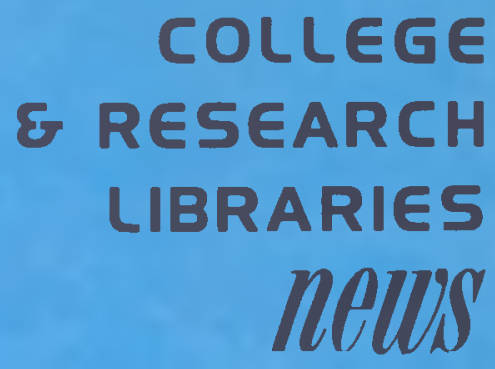

NO. 8 SEPTEMBER 1976

\title{
ACRL Officers for 1976/77
}

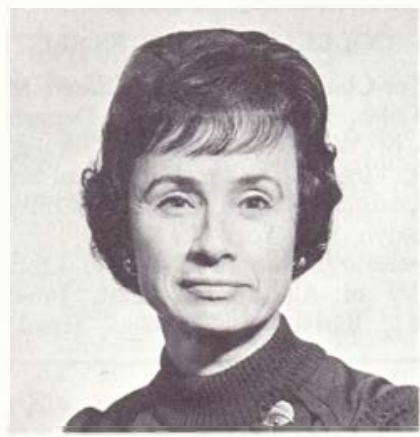

Connie R. Dunlap

Connie R. Dunlap, university librarian at Duke University, Durham, North Carolina, will serve as president of the Association of College and Research Libraries for 1976/77. As president of ACRL, Dunlap chairs the ACRL Board of Directors, the ACRL Executive Committee, and the ACRL Conference Program Planning Committee for the 1977 Annual Conference in Detroit. She also serves as a member of the Choice Editorial Board and as an ex-officio member of all other units of ACRL. As president of the division, Dunlap represents ACRL on the ALA Conference Program Committee for the Detroit Conference and on the ALA SCMAI Committee on Policy Implementation. Dunlap will also represent ACRL and ALA to other educational and professional organizations, such as the American Council on Education.

In addition to her tenure as vice-president/ president-elect of ACRL during 1975/76, Dun- lap's service to ACRL and ALA includes chairing the Clarence Day Award Jury in 1974/75, the Acquisitions Section of the ALA Resources and Technical Services Division, and the Organization Committee of RTSD. Dunlap served as president of RTSD in 1972/73. She has been a member of the ALA Council since 1974.

Eldred R. Smith, director of university libraries at the State University of New York at Buffalo, is the newly elected vice-president/ president-elect of ACRL. In the recent elections, Smith received 1,192 votes. His opponent, Johnnie Givens, head librarian at Austin Peay State University, Clarksville, Tennessee, received 1,033 votes.

In the past, Smith has served ACRL as a member and chairman of the Committee on Academic Status and as chairman of the ACRL University Libraries Section. He has been a member of the ALA Standards Committee, the RTSD Library Materials Price Index Committee, and the Library Research Round Table. He is currently the chairman of, and one of ACRL's representatives to, the ACRL/Association of Research Libraries Joint Committee on University Library Standards.

As vice-president of ACRL, Smith will serve as a member of the ACRL Board of Directors, the ACRL Executive Committee, and the ACRL Planning Committee. He will chair the ACRL Conference Program Planning Committee for the 1978 Annual Conference in Chicago; and he will represent ACRL on the ALA Committee on Appointments, the ALA Budget Assembly, and the ALA Conference Program Committee for the 1978 conference. At the close of the 1977 Annual Conference, he will become ACRL's thirty-ninth president. 


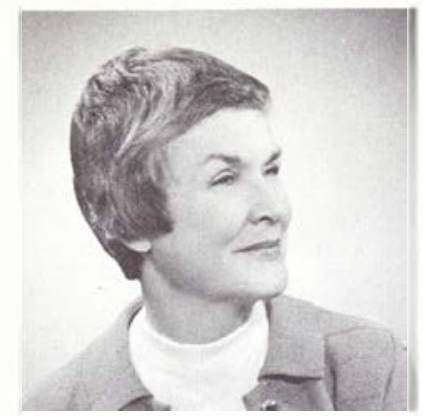

Jane G. Flener

Jane G. Flener, associate director of libraries for public services at the University of Michigan, Ann Arbor, and Pauline Atherton, professor at the School of Information Studies, Syracuse University, Syracuse, New York, were recently elected to serve four-year terms as directors-at-large on the ACRL Board. Flener received 1,661 votes; Atherton, 956. Their opponents, Louis C. Moloney, director of the Learning Resources Center at Southwest Texas State University, San Marcos, Texas, and Thomas E. Strader, library direcior at Towson State College, Baltimore, Maryland, received 904 votes and 657 votes, respectively.

The results of the ACRL section elections follow. For each position, the elected candidate is listed first. The number of votes earned by each candidate is listed in parentheses.

\section{AGRICULTURE AND BIOLOGICAL SCIENCES SECTION}

Vice-Chairman/Chairman-Elect: Doris Bolef, Assistant Dean for Learning Resources, College of Medicine, East Tennessee State University, Johnson City, Tennessee (97); Nancy F. Hardy, Instructor, School of Library and Informational Science, University of Missouri-Columbia, Columbia, Missouri (58).

Secretary: Linnea Sodergren, Health Manpower Bureau, H.E.W., Chicago, Illinois (121); Teresa M. Libro, Biomedical Librarian, Wausau Hospitals, Wausau, Wisconsin (28).

\section{ANTHROPOLOGY SECTION}

Vice-Chairman/Chairman-Elect: Marilyn L. Haas, Reference Librarian and Bibliographer for Anthropology and Linguistics, State University of New York at Buffalo, Buffalo, New York (68); Anne K. Beaubien, Social Sciences Reference Librarian and Bibliographic Instructor, University of Michigan, Ann Arbor, Michigan (59).

Member-at-Large: Hazel Johnson, Social Sciences Bibliographer, University of Pittsburgh, Pittsburgh, Pennsylvania (82); Max L. Plaut, Reference Librarian, Field Museum of Natural History, Chicago, Illinois (45).

\section{ART SECTION}

Vice-Chairman/Chairman-Elect: Antje Bultmann Lemke, Professor, School of Information Studies, Syracuse University, Syracuse, New York (157).

\section{ASIAN AND AFRICAN SECTION}

Vice-Chairman/Chairman-Elect: John A. Eilts, Head, Near Eastern Division, University of Michigan Library, Ann Arbor, Michigan (94); Robert Edmond Booth, Director, Division of Library Science, Wayne State University, Detroit, Michigan (36).

Secretary: Josephine Riss Fang, Professor of Library Science, Simmons College, Boston, Massachusetts (69); Mohammed M. Aman, Director, Division of Library and Information Science, St. John's University, Jamaica, New York (67).

Member-at-Large: David G. Donovan, Associate Director of Libraries, University of Notre Dame, Notre Dame, Indiana (67); Rosalie Cuneo Amer, Head, Technical Services, Learning Resource Center, Cosumnes River College, Sacramento, California (63).

\section{COLLEGE LIBRARIES SECTION}

Vice-Chairman/Chairman-Elect: Mary Louise B. Cobb, Head, Cataloging Department, College of William and Mary Library, Williamsburg, Virginia (467); Betty-Carol Sellen, Chief, Circulation Division, Brooklyn College Library, Brooklyn, New York (211).

Secretary: Robert K. Bruce, Librarian, University of Alaska-Southeast, Juneau, Alaska (405); Barbara J. Williams, Head Librarian,

News items for inclusion in C\&RL News should be sent to Mary Frances Collins, Assistant Director of Libraries for Technical Services, University Library ULB-35A State University of New York at Albany. 1400 Washington Ave. Albany, NY 12222. Advertising (including classified ads) should be sent to Leona Swiech, Advertising Olfice, American Library Association, 50 E. Huron St., Chicago, IL 60611 . Production and eirculation matters are handled by ALA Central Production Unit, at the above address.

News editor: Mary Frances Collins Assistant Director of Libraries for Technical Services. State University of New York at Albany, Albany. Editor: Richard D. Johnson, Milne Library, State University College, Oneonta, New York i3820. President, ACRL: Connie R. Dunlap. Executive Secretary, ACRL: Beverly P. Lynch.

College \& Research Libraries is published by the Association of College and Research Libraries, a division of the American Library Association 17 times yearly- 6 bimonthly journal issues and 11 monthly (combining July-August) News issues-at |201-05 Bluff St., Fulton, MO 6525I. Subscription, $\$ 15.00$ a year or to members of the division. $\$ 7.50$, included in dues. Second-class postage paid at Fulton, Missouri 65251.

(C) American Library Association 1976. All material in this journal subject to copyright by the American Library Association may be photocopied for the noncommercial purpose of scientific or educational advancement. 
South Carolina State College, Orangeburg, South Carolina (273).

\section{COMMUNITY AND JUNIOR COLLEGE LIBRARIES SECTION}

Vice-Chairman/Chairman-Elect: J. Daniel Vann, III, Chief Librarian, Staten Island Community College, Staten Island, New York (164); Sidney August, Director, Division of Educational Resources, Community College of Philadelphia, Philadelphia, Pennsylvania (127).

Secretary: Kathlyn King Lundgren, Audiovisual Librarian, Nebraska Western College, Scottsbluff, Nebraska (184); Joseph F. Lindenfeld, Director of Library Service, Shelby State Community College, Memphis, Tennessee (109).

\section{EDUCATION AND BEHAVIORAL SCIENCES SECTION}

Vice-Chairman/Chairman-Elect: Joe Mapes, Education Librarian, University of Colorado, Boulder, Colorado (165); Lawrence W. Marble, Education Reference Librarian, Temple University, Philadelphia, Pennsylvania (97).

\section{LAW AND POLITICAL SCIENCE SECTION}

Vice-Chairman/Chairman-Elect: Signe E. Larson, Chief, Research Services, Natural Resources Library, U.S. Department of the Interior, Washington, D.C. (130) · Egon A. Weiss, Director, U.S. Military Academy Library, West Point, New York (70).

Secretary: Joan L. Chambers, Government Publications Librarian, University of Nevada, Reno, Nevada (104); Marie Morris, Reference Librarian, Emory University, Atlanta, Georgia (89).

Member-at-Large: Alice D. Ball, Executive Director, Universal Serials and Book Exchange, Washington, D.C. (103); Aaron Hause, Head Documents Librarian, University of Arizona, Tucson, Arizona (90).

\section{RARE BOOKS AND MANUSCRIPTS SECTION}

Vice-Chairman/Chairman-Elect: Terry Belanger, Assistant Professor, School of Library Service, Columbia University, New York, New York (212); Marian Mackay Orgain, Assistant Director of Libraries and Curator of Special Collections, University of Houston, Houston, Texas (153).

Member-at-Large: William P. Wreden, Books and Manuscripts, Palo Alto, California (187); Anne C. Skoog, Fine and Rare Books Librarian, Carnegie-Mellon University, Pittsburgh, Pennsylvania (172).

Member-at-Large: Marion E. Brown, Head, Department of Rare Books and Special Collections, University of Toronto Library, Toronto, Ontario, Canada (247); Minnie E. Paugh, Special Collections Librarian, Montana State University, Bozeman, Montana (107).

\section{SLAVIC AND EAST EUROPEAN SECTION}

Vice-Chairman/Chairman-Elect: Eugene E. Petriwsky, Assistant Director for Technical Services, University of Colorado Libraries, Boulder, Colorado (50); David P. Rose, Librarian for Slavic Studies, University of North Carolina, Chapel Hill, North Carolina (46).

Member-at-Large: Carol Ann Leadenham, Catalog Librarian, University of Arizona, Tucson, Arizona (52); Marvin F. Bielawski, Subject Analyst, Princeton University Library, Princeton, New Jersey (44).

\section{UNIVERSITY LIBRARIES SECTION}

Vice-Chairman/Chairman-Elect: Millicent D. Abell, Associate Director of University Libraries, State University of New York at Buffalo, Buffalo, New York (641); Susan Brynteson, Associate Director for Technical Services, University of Tennessee Libraries, Knoxville, Tennessee (593).

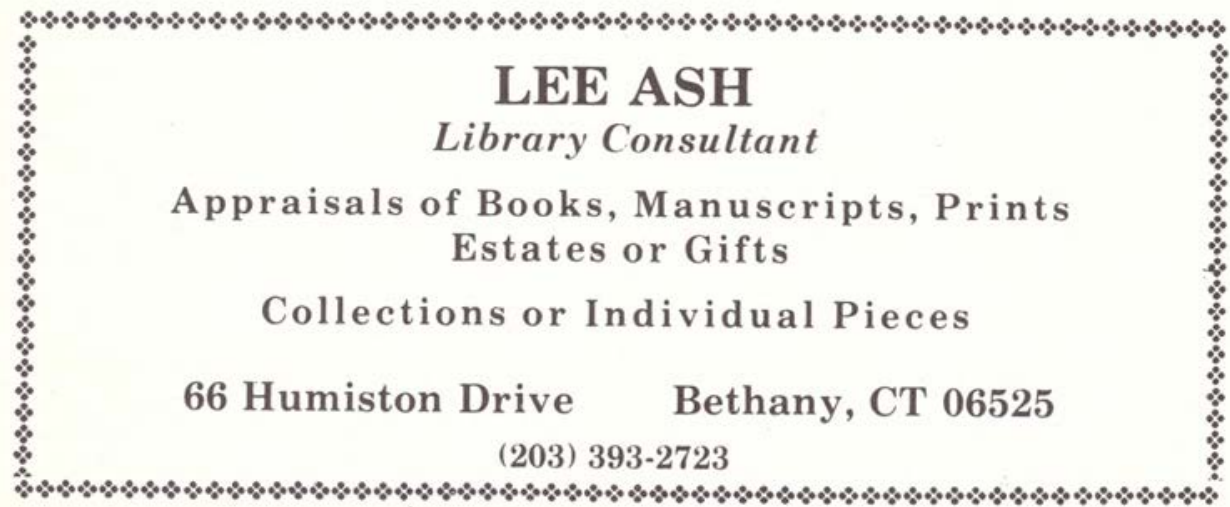

